\title{
No Global War? A Role for Democratic Global Federalism
}

\author{
by \\ Myron J. Frankman* \\ Department of Economics \\ McGill University \\ 855 Sherbrooke St. West \\ Montreal, Quebec Canada H3A 2T7 \\ inmf(a.musicb.mcgill.ca
}

Cite: Frankman, Myron J. (1997). "No Global War? A Role for Democratic Global Federalism." Journal of World-Systems Research 3:321 - 338.

C 1997 Myron J. Frankman

* Revised version of a paper prepared for the Annual Meetings of the Society for Socialist Studies, Brock University, June 3, 1996. This paper was prepared during the author's stay as Visiting Academic in 1995-96 in the Department of Economics, Faculty of Economics and Administration, Universidad de Chile, Santiago.

\section{INTRODUCTION}

Between 1943 and 1946 E.B. White wrote a series of editorials in The New Yorker magazine supporting democratic federal world government. In his editorial of June 1, 1946, he wrote:

World government is an appalling prospect... . Certainly the world is not ready for government on a planetary scale. In our opinion, it will never be ready. The test is whether the people will chance it anyway -- like children who hear the familiar cry, 'Coming whether ready or not!' At a Federalist convention the other day, Dean Katz of the University of Chicago said, 'Constitutions have never awaited the achievement of trust and a matured sense of community; they have been born of conflicts between groups which have found a basis for union in spite of deep suspicions and distrusts.' The only condition more appalling, less practical, than world government is the lack of it in this atomic age. (185-86)

In fact, the issue is not whether we shall be governed globally, but rather by whom and on what basis. The international realm is not one of anarchy as the realists would have us believe, but rather one of order: of rules, procedures and accepted norms of behavior associated in part with what are termed "international regimes" (Krasner 1983), each dedicated in principle to a separate functional domain. Global governance is not something that is to be created, but rather something to be altered in the public interest. The governance of the globe is currently configured by a shifting set of ill-coordinated actors: among them the one remaining super-power and, to a lesser extent, other strong states, as well as powerful individuals and a number of large transnational corporations 
and financial institutions. Whereas Le Monde Diplomatique (1995) speaks of les nouveaux maitres du monde, Robert Cox has summed up our cur rent system of global governance with the phrase nébuleuse: "There is, in effect, no explicit political or authority structure for the global economy. There is, nevertheless, something there that remains to be deciphered, something that could be described by the French word nébuleuse or by the notion of 'governance without government."' (1992/1996: 311) [1]

[Page 321]

Journal of World-Systems Research

Our current system of global governance is one of rule by the few. While an increasing number of the world's countries are procedural or even substantive democracies, global governance is far from democratic. Moreover, those international institutions where diverse voices are heard are precisely those with not only the least power to act on matters of substance, but with the most precarious financing. Imagine what the circumstances of national federal governments would be today if they had to rely for funds on a combination of voluntary assessments and proceeds from the sale of greeting cards. Without both cooperation and funding by the US, actions approved in the UN General Assembly are essentially dead letters. The mid-1970s General Assembly resolutions creating a New International Economic Order (Resolutions 3201 and 3202 , 6th Special Session, May 1, 1974), and that proclaiming the Economic Rights and Duties of States (Resolution 3281, 29th Session, December 12, 1974) were doomed by the de facto veto of the US before they were even approved. In the International Monetary Fund the US has had a de jure veto on matters requiring a special majority (of first $80 \%$ and later $85 \%$ ) of the weighted votes since the Fund was created at Bretton Woods in 1944 based largely on the American drafted proposal. Delays by the US in approving subsequent increases in country quotas (the source of the Fund's own resources) have been a key element in the conversion over the years of the IMF from a credit union to a powerful global financial watchdog. (Kenen 1989)

Like it or not, we have a global culture, one which the governing few have had a major hand in shaping. If we consider a culture to be characterized as a network of conversations, then it follows that cultures change with alterations in the content of the conversations. (Maturana 1995: 132) Conversations, and hence cultures, h ave changed throughout the world both by chance and by systematic orchestration by powerful private interests. (Herman and Chomsky 1988; Marchak 1991; Saul 1995)

[Page 322]

Journal of World-Systems Research

As the evolving global culture is one that presently celebrates individual rights without responsibilities, we have witnessed over the past two decades substantial increases in 
inequality of wealth and income. Comparative international data on income disparities are at best fragmentary and of recent vintage, but one estimate of the ratio of the income of the richest $20 \%$ to that of the poorest $20 \%$ of the world's population, based on a ranking by national average income, suggests a gap which widened from 30/1 in 1960 to 59/1 in 1989. (United Nations Development Programme 1992: 34-36 \& 96-103) An account in a joint IMF-World Bank journal even counsels us to forget income convergence between countries and even regionally within developing countries, unless there are "serious changes in economic policies" in those countries. (Pritchett 1996:43) The Human Development Report 1996 identifies a number of types of prominent growth patterns, among them jobless growth, voiceless growth, rootless growth, futureless growth and ruthless growth. Associated with "ruthless growth" was an absolute decline of the per capita income of one billion people over the period 1980-93 (UNDP 1996:2) A recent evaluation for the United States showed that between 1976 and 1989 the share of the nation's net wealth held by the richest $1 \%$ of the country's households had increased from $21 \%$ to $36 \%$, reversing a prior decade-long decline. (Wolff 1995: 67) Past gains in income, job security and access to social services, often achieved by way of concerted political action, have been weakened, if not actually swept aside.

\section{NATIONAL ADJUSTMENTS TO GLOBALISM}

Robert Gilpin has characterized our current predicament as being the dilemma of the limits of national welfare capitalism in a non-welfare international capitalist world.(1987: 60-64) We live in an integrated world economy with few effective control mechanisms to provide offsets to the varied national impacts of global economic activities. Indeed, governments, acting in response to external constraints, pursue strategies that reinforce some of the adverse national consequences. Andre Drainville has elaborated on this in his description of global accumulation being validated politically by state-bound democracies and on their ability to strike social compromises. Drawing on Desmond King, Drainville describes how citizens are called upon to embrace economic rationality and "lead the assault on ... the social rights of citizenship". (1995:60)

[Page 323]

Journal of World-Systems Research

People cannot be counted on, however, to faithfully function indefinitely in the interests of global accumulation. As the divergence-widening effects of the current scheme of global governance with its supporting national manifestations become more and more obvious, reactions begin to set in. One common reaction is to point to "others" as being the threat to one's job (Richmond 1994). But immigration controls are not a solution to the employment problem, which is but one of a range of human interactions which can only be dealt with successfully by collective action on a global scale. The insistence that national solutions be sought to problems generated by global accumulation is essentially a recipe to "divide and conquer." Combining a closing of borders to immigration with an insistence that poor countries resolve their own problems serves to exacerbate two of the 
elements (population pressure and inequality) which Christopher Chase-Dunn and Bruce Podobnik have identified as causal factors heightening the probability of future "core wars". (1995: 13)

The Latin Americans have invented a word to describe a procedural democracy where participation is not merely limited, but actively suppressed: a democradura -- hard democracy. (O'Donnell and Schmitter 1986: 41) In its original usage the phrase referred to a pact between civil authorities and the military to establish limited democracy. The term seems more broadly applicable: are we not already seeing the signs of an emerging democradura in a number of northern countries, including Canada, as the will to maintain social programs erodes? (Greider 1992; Saul 1995) The limits on state action arising from the (real or anticipated) hypersensitivity of financial markets has led to what Susan Strange has called the end of opposition from established parties: differences between policies of government and opposition parties disappear, as "society, economy and authority are no longer bound by the frontiers of the territorial state." (Strange 1995: 291,301) One hastens to add that where opposition does remain, it is treated as a fringe (either dangerous or irrelevant) that unrealistically refuses to accept the new and (ostensibly) immutable circumstances of state limits.

[Page 324]

Journal of World-Systems Research

\section{RESPONDING GLOBALLY}

Paradoxically, if we are to save the world from breakdown occasioned by capitalism, we must once again save the capitalists from their global excesses, just as the earlier creation of national welfare states saved the capitalists from their excesses at the national level. The same logic that propelled the creation of the welfare state and the extension of democracy at the national level, now must be extended to the global level, not with the express purpose of making the world safe for capitalism, although that may be the effect, but rather to make the world safe: safe for the common person, safe for civil rights, safe for our children and grandchildren, safe for the flora and fauna.

A welfare state, whether national or global, requires a structure of government to shape the programs, to finance them, and to respond to changed circumstances. The difficulty which confronts us in our current situation is that our ability to act at the global level is severely restricted by an institutional framework with limited responsiveness, owing to the recalcitrance of major powers. We are limited as well by our misperception that trying to solve problems at the national level is wholly appropriate for most issues.

Our tacit or overt acceptance of functional globalism, of the sort proposed by Daniel Mitrany (1943), that pretends that most issues of global significance are purely technical and best left to experts represents another major limit. In fact, few problems are purely

technical. Wherever there is a human dimension to a decision, discretion and preferences 
enter into play; we leave the realm of the exact and enter the realm of the political. To capitulate to the claims that only the experts can decide, for example, as in the current conventional wisdom regarding independence of central banks (Eijffinger and De Haan 1996; Gormley and De Haan 1996) and the IMF, is to concede to a select group sovereign rights, which few of the world's remaining monarchs even exercise. Political problems require political solutions within a context where a range of opinions can be heard. Those which are global problems require global political solutions.

[Page 325]

Journal of World-Systems Research

The idea of global government is hardly new. To give but a sample, we can trace the idea back to Immanuel Kant (1796), John Hobson (1915), Leonard Woolf (1916), and Harold Laski (1921). In 1925 Laski was already arguing that world government was one of the implications of modern conditions and that federalism would be the most appropriate form. (Long 1993: 365) Democratic global federalism is also an idea that has been around for awhile. At the time that official representatives in San Francisco in October 1945 were but a few days away from signing the United Nations charter, The New York Times carried a front page account of a conference in Dublin, New Hampshire whose distinguished delegates signed a declaration calling instead for global democratic federalism. (New York Times, October 17, 1945, p. 1) World Federalists have long been active in Canada and published a periodical (World Federalism) espousing the idea between at least 1955 and 1974 .

W. Warren Wagar dismissed federalism and world federalism one-quarter century ago: the former as "so much cold mutton in the second half of the twentieth [century]"; the latter as a project that feeds "on a wide assortment of deadly illusions", yet whose followers were regarded as so harmless (at the time) that "governments let them continue unmolested and unnoticed." (Wagar 1971: 32-36) Is there reason to believe that federalist structures offer any promise today in dealing with our problems? Federalism within nations has been given an impetus by the neo-liberal emphasis on the downsizing of the state and its associated reallocation of functions from the center to the regions. Supranational federalism within the European Union (EU) has found strong support in regions, like Catalonia, whose relations with their national capitals have been marked historically by tensions. In a fanciful scenario Wagar suggests that a world state -- the Commonwealth -- might emerge through the voluntary association of a growing number of states with "World Party" governments. He admits that he currently sees no inkling of a World Party on the political horizon. (Wagar 1996: 10-15) Is it any more far-fetched to imagine that the once 6 member European Common Market, now 15 member European Union, which already has over a dozen willing adherents at its doorstep [2], might eventually through a continuous process of expansion and structural modification include all of the world's people and come to be "known simply" as the Union, with the Union Parliament representing the people of the various members, as does the EU Parliament today, and not their national governments? 
[Page 326]

Joumal of World-Systems Research

What is new today is the urgency and the possibility for bringing the project into being. Consider the logistics of bringing together the American Founding Fathers in Philadelphia in 1776 or the Fathers of Canadian Confederation in Charlottetown, Prince Edward Island in 1867. Even bringing delegates to San Francisco in 1945 was a major undertaking. To physically convene today a representative cross section of the human population would be child's play compared to these earlier assemblies.

Logistics is obviously not the issue; the issue is always one of will, which would appear to be growing daily with our expanding sense of the global interdependence of a host of urgent issues. We have already witnessed several instances of the gathering of appreciable numbers of citizen delegates at unofficial meetings that have paralleled major world summits, including some 30,000 women, representing 2,000 NGOs at the Women's Forum which paralleled the September 1995 Beijing United Nations Fourth World Conference on Women. The elaboration of numerous alternative treaties at the 1992 Rio de Janeiro United Nations Conference on Environment and Development -- the Earth Summit -- by the International Forum of NGOs and Social Movements (Foro Internacional 1993) is but one additional indication that the time may have arrived for the people of the world to take bolder action to wrest control of global processes from les nouveaux maitres du monde. NGO representation, both official and unofficial, at world summits has the potential to transform politics; to create a global politics where the people have voice to complement international fora where only states have voice.

Preoccupations with the possibility of devastating war and the escalating costs of deterrence, with the attendant neglect of social needs, also focus attention on global institution building to maintain and extend world peace. World Systems theorists who have studied Kondratieff long economic cycles (K-Waves) have been struck by the persistently recurring interaction between war and economic growth processes. (Goldstein 1988) Chase-Dunn and Podobnik see the current K-Wave leading to a 50-50 likelihood of a core war in the 2020 s decade and urge us to continue laboring to avoid that eventuality (1995: 32) George Modelski and William R. Thompson wonder whether the current nineteenth K-Wave might avoid an associated global war given, inter alia, "denationalized industrial production, increased political management capacities on the part of international organizations, and the continuing diffusion of democratic institutions." (1996: 225) Their message is a clear one: there is continuing effort to be made if war is to be avoided. However, as Wagar reminds us, peace, like happiness, is a by-product; it is the creation of a "new world civilization" that is the work at hand. (1971: 36)

[Page 327]

Journal of World-Systems Research 
Returning to the factors identified by Chase-Dunn and Podobnik as either exacerbating or mitigating the likelihood of a major war; inequality, international economic integration, international political integration and disarmament (1995: 13) are all areas where substituting the voice of global citizens for the voice of national interests might well move us forward. As Immanuel Wallerstein puts it: "Perhaps we should tiptoe into an uncertain future, trying merely to remember in which direction we are going." (1991: 229). To build a global federal structure may be our best guarantee to assure that we can preserve that which is of value that is close to us and to permit the directional shifts perceived to be necessary when we appear to be veering off course.

If we achieve global democratic federalism, the eventual form will reflect the outcome of lengthy political processes, with variations from one level of the hierarchy to another and from one jurisdiction to another at the same level. There is no reason to believe that existing differences in federal structures between countries will disappear, nor any way to predict what form will emerge at the global level. We might see a greatly strengthened United Nations, but this is unlikely to help us much with our dilemmas born of neoliberalism, unless there is a major sea change in the visions of national governments. A People's Assembly that would provide the UN with a bicameral legislative structure might well be a possible scenario. Citizen involvement and a global assembly of representatives of the world's people could be an important counter weight to a system where states have the sole voice. (Heinrich 1992; Held 1995: 278-83; Wagar 1996) For as Claude Julien reminds us: "States don't have friends; they have interests." (1996: 16) For Canadians, envisioning forms for global federal structures should come as naturally as getting out of bed in the morning.

Let us not be timid about global government. I subscribe in principle to the notion of subsidiarity, but what has been called marble cake federalism is more likely to be the working result. Responsibilities may rest at a particular level, but higher levels do not keep silent when problems arise. Similarly, pressures may also go from a lower level to a higher level as new tensions emerge. The point of democratic institutions is precisely not to freeze important elements of the structure of governance indefinitely because of the de facto or de jure veto of a key player.

[Page 328]

Journal of World-Systems Research

\section{THE CENTRALITY OF CITIZENS}

The phrase democratic deficit is used with frequency in the context of European integration to focus attention on the relative exclusion of the people from the shaping of a united European. (Fischer 1995: 203-222; Norton 1996: 177-93) Those who speak of a democratic deficit seek to provide Europeans with both responsibilities and an effective 
voice in the conduct of the affairs of the Union. However important the right to a European passport and free movement within the Union may be, a Europe of the people depends on the individual exercise of collective responsibilities with one's counterparts in other European countries. This is one of the messages that has appeared in a series of monthly articles on European citizenship ("Une Europe des Citoyens") between March and June 1996 in Le Monde Diplomatique. Articles in the May issue by Pierre Behar (1996) and Paul Thibaud (1996) support a federal Europe in which citizens play an important role and both refer to that as having been the vision of General de Gaulle.

Drainville has raised important questions about "construction of citizenship in the world economy", suggesting that in fact citizens are presently banished from the space of the world economy. (1995: 71) As Drainville observes, "there is something radically important about conceptualizing the world economy as a social space in the making." (1995: 70) The very act of describing serves to alter; the act of naming can create. To see our current situation as one of exclusionary global governance is to raise the possibility of action. Drainville speaks of reconstructing, reimagining and remapping world politics. (1995: 70) That is precisely the task: to create a real "world politics" which would give substance to a phrase that has long been a misnomer. What we label today as world politics is in fact the realm of anti-politics (Ferguson 1990; Mulgan 1994), of the experts and of the diplomats whose instructions carefully delineate their limits. The NGOs represents an ongoing important stepping stone in the broadening of world politics and in the construction of world citizenship. Their achievements should renew our hope that what appear to be oppressive and unchanging structures are in reality processes in motion and strengthen our resolve to continue our collective efforts.

[Page 329]

Journal of World-Systems Research

Those who reject supranational government as escapism would appear to be affirming that citizen participation is a well-established reality in most of the world's democracies and that citizens acting through their governments are equal to the task at hand. In fact, democratic deficits are ubiquitous and have been growing with the advance of neoliberalism. To the best of my knowledge democratic deficits are not measured, not reported, and not the object of serious criticism in the way that government budget deficits are. Indeed were national democratic deficits to be reduced markedly, the hysteria concerning fiscal deficits and the size of the state might well be dispelled as an outcome of the resulting public debates. It is not only regional citizens and world citizens that are to be created, but true national and local citizens must also be either created or recreated Mitrany suggested that "the performance of a number of common functions is the way to create a normal community." (Mitrany in Long 1993: 371) For too long now we have been witnessing the disappearance of common functions. Our challenge today is to create a world in which the number of common functions performed by individuals is markedly expanded in order to swell the ranks of the politically active at all levels. 
The task confronting the peoples of the world is the major one of changing perceptions of the nature of our current reality and then changing behavior to join in and create a public debate at all levels and to engage in political action: that is the new world civilization and it is already in formation. Nor is the "Academy" being left in the dust: a keyword search of the on-line public access catalogue of any major university library will identify an outpouring of new publications dealing with either global governance or democracy, far too numerous to list here. Civil society must either be created or strengthened everywhere. The democratic deficit is partly of our own making in so far as we have ceased to behave collectively. Our myopia, cynicism, withdrawal, avoidance of collective responsibility, and deference to authority and technical experts have been carefully nurtured by an educational system in the service of nationalism. We often hear attributed to H.G. Wells a phrase relating to the race between education and catastrophe. In fact, where Wells' sentiment appears in context, we find that he addresses the evils of nationalism and of education distorted by those who choose to use nationalism for personal advantage. (Wells 1932: 650) Most of us are products of an educational system that has done its best through pass ive learning to neutralize knowledge and of a society with an anti-political bent. That many of us are, nonetheless, active and political is a tribute to the resilience of the human spirit of justice and gives yet additional cause for hope. Moreover, even in the classroom, professing is increasingly giving way to facilitating. The spreading emphasis on participation leaves few of us unchanged.

[Page 330]

Journal of World-Systems Research

The construction of meaningful world citizenship is not likely to be a direct by-product of "globalization from above." Indeed, meaningful citizenship at whatever level is unlikely to result from the activities of the ne buleuse, which tend not to focus on participatory democracy, but rather on "good governance", which is something said to be expressed by a ratio of government expenditure to gross product. The construction of meaningful world citizenship is taking place daily. "Globalization from below" with its daily crossborder, cross-cultural interactions, is the incessant process by which our mental images are being altered. Conscious perceptions may not matter in the early stages of formation of our sense of planet-wide interdependence. The process is in motion and the participants may only be dimly aware of the transition of which they are currently part. We have yet to recognize the opportunities that are arising daily. There are limits to the role of civil society at all levels, especially at the transnational or global level, but the frontier of action is an ever-changing one. In an era of positive-feedback, particularly nourished by electronic communications, those limits can change swiftly; witness the events following Perestroika and, less than five years later, the fall of the Berlin Wall.

To get from here to there will require major efforts to spread the word: we live on one small planet and we are one people with a common culture. We may speak different languages, we may have distinct local customs, we may look different, but we are one. Those of us committed to saving local autonomy, must support efforts to strengthen the 
global umbrella. Elise Boulding (1988) has written of crafting a global civil society. The time has come to craft as well the global democratic federal structures of governance to go with that. If individuals become citizens instead of onlookers, then the prospect of the public and the political spaces becoming far more active venues could well mean the death of expert-driven exclusionary anti-politics where decisions currently masquerade as technical necessities.

[Page 331]

Journal of World-Systems Research

\section{CONCLUSION}

I think it appropriate to note that I wholeheartedly support the idea of global taxation and redistribution, essential elements for reducing inequality. (Frankman 1996) Nonetheless, I reject the global tax proposal which seems to have achieved the most popularity of late, the Tobin Tax of up to $0.5 \%$ of the value of each foreign exchange transaction, insofar as it deals with effects and not causes. Tobin's original intent was not to raise revenue, but to "throw sand in the wheels of international finance". By 1995 foreign exchange transactions were estimated to exceed US $\$ 1.2$ trillion per day. This hypermobility of capital represents a veritable sword of Damocles perceived to threaten any government contemplating measures that diverge from the current market conception of proper public sector behavior. (Haq, Kaul and Grunberg 1996).

I favor instead the creation of a single world currency with appropriate supporting institutions, which, incidentally, is James Tobin's preferred scenario: according to Tobin the best solution would be "a common currency, common monetary and fiscal policy, and economic integration." (Tobin 1978: 154). The "freedom" to devalue that a separate currency accords to a nation offers no guarantee that generalized benefits will be realized. (Bourgignon, de Melo \& Morrisson, 1991) Insofar as exchange rates play a key role in the frantic quest for national competitiveness, international economic integration that brings their elimination, if accompanied where necessary by appropriate offsets, further reduces the likelihood of war.

One ingredient is not made explicit in Tobin's list: global democratic institutions that presumably would shape a fiscal policy to meet the needs of disadvantaged individuals and regions wherever they may be, just as national institutions presently serve that function with varying degrees of success. My own work on the global economy has brought me to cross the line from the technical to the political. Institutions intended to achieve global social justice must be embedded in a global political system where the peoples of the world can give expression to their will in a democratic context. The political awareness that is necessary to rescue the state, currently under both strain and merciless attack, is the very same awareness that is necessary to construct political democracy at all levels of the hierarchy. What is needed is not a blind allegiance to the 
Father Land or the Mother Country, right or wrong, but an appreciation of the shifting limits of sovereignty and of the ever-shifting locus for action in distinct problem areas.

[Page 332]

Journal of World-Systems Research

Political awakening associated with a local issue may be the start of a long march toward support for global government, given the clear line of causation from supposed inevitabilities at the local level to power relationships extending to the global scale. To the extent that the fallout of neo-liberal economic policy reawakens collective action, the next round may well feature a broadened focus, extending from the local to the global, in recognition of our interdependence and the common problems we confront around the world, whose resolution lies beyond local jurisdiction. That common perception is the current reality of the many NGO members who network regularly with counterparts in many countries of the world.

In the very first paper that I presented on global taxation in 1970 , I closed with the following quote from Bertrand Russell: "It is not by pacifist sentiment, but by world-wide economic organization, that civilized mankind is to be saved from collective suicide." (Russell 1934: 510; Frankman 1971) Today, it is clear to me that Russell specified a necessary condition, but not a sufficient one for avoiding collective suicide. For E.B. White, the sufficient condition was unambiguous: "Peace is the product of responsible government." (White: 41) That ideal must be our continuing objective as educators and citizens if the promise of no global war is to be realized for the 19 th and subsequent $\mathrm{K}$ waves.

\section{END-NOTES}

1. And: "Far from being a sinister occult power, the nébuleuse may turn out to be a Wizard of Oz. Perhaps no one, or no coherent structure, is really in control." For Cox, Le Monde Diplomatique's phrase "conjures up a coherent strategy of dominance, virtually a conspiracy." (Cox 1996: E-Mail)

2. Eurobarometer sampled opinion within the EU countries as to the willingness in 1995 of respondents to see each of 24 European countries join the Union in the future. Spanish respondents were the most generally favorable to expansion in that they were amenable to admitting most of the countries; their lowest score was $44 \%$ in favor of admitting Latvia. (1996: B62-63)

[Page 333]

Journal of World-Systems Research 


\section{REFERENCES}

Behar, Pierre (1996). "Repenser le couple franco-allemand." Le Monde Diplomatique 43 (May), 4-5.

Boulding, Elise ( 1988). Building A Global Civic Culture: Education for an Interdependent World. New York: Columbia University, Teachers College Press.

Bourgignon, F., J. De Melo, \& C. Morrisson (1991). "Poverty and Income Distribution During Adjustment: Issues and Evidence from the OECD Project." World Development 19 (Nov.), 1485-1508.

Chase-Dunn, Christopher and Bruce Podobnik (1995). "The Next World War: WorldSystem Cycles and Trends." Journal of World-Systems Research 1 (no. 6).

Cox, Robert W. (1992/1996). "Global Perestroika." In Cox, (1996) Approaches to World Order. Cambridge: Cambridge University Press. 296-313.

Cox, Robert W. (1996). E-mail message. (December 28).

Drainville, André (1995). "Of Social Spaces, Citizenship and the Nature of Power in the World Economy." Alternatives 20 (Jan.-March), 51-79.

Eijffinger, Sylvester, \& Jakob De Haan (1996). The Political Economy of Central-Bank Independence. Princeton Special Papers in International Economics No. 19. (May).

Eurobarometer: Public Opinion in the European Union (1996). No. 45 (Spring).

Ferguson, James (1990). The Anti-Politics Machine: Development, Depoliticization, and Bureaucratic Power in Lesotho. New York: Cambridge University Press.

[Page 334]

Journal of World-Systems Research

Fischer, Thomas C. (1995). The Europeanization of America: What Americans Need to Know about the European Union. Durham, NC: Carolina Academic Press.

Foro Internacional de ONGs y Movimientos Sociales (1993). Construyendo el Futuro: Tratados Alternativos de Rio 92. Montevideo: Pacto Acción Ecológica de América Latina.

Frankman, Myron J. (1971). "Financing International Cooperation: An Immodest Proposal." http://vm1.mcgill.ca/ inmf/http/ic71.text. 
Frankman, Myron J. (1996). "International Taxation: The Trajectory of an Idea from Lorimer to Brandt." World Development 24 (May), 807-20.

Gilpin, Robert (1987). The Political Economy of International Economic Relations. Princeton: Princeton University Press.

Gormley, Laurence and Jakob De Haan (1996). "The Democratic Defic it of the European Central Bank." European Law Review 21 (April), 95-112.

Greider, William (1992). Who Will Tell the People: The Betrayal of American Democracy. New York: Simon \& Schuster.

Haq, Mahbub ul, Inge Kaul and Isabelle Grunberg, eds. (1996). The Tobin Tax: Coping with Financial Volatility. New York: Oxford University Press.

Heinrich, Dieter (1992). The Case for a United Nations Parliamentary Assembly. New York \& Amsterdam: World Federalist Movement.

Held, David (1995) Democracy and the Global Order: From the Modern State to Cosmopolitan Governance. Stanford: Stanford University Press.

Herman, Edward S. and Noam Chomsky (1988). Manufacturing Consent: The Political Economy of the Mass Media. New York: Pantheon Books.

[Page 335]

Journal of World-Systems Research

Hobson, John (1915). Towards International Government. New York: The Macmillan Company.

Julien, Claude (1996). "Une Europe des citoyens (II) L'outil et le projet." Le Monde Diplomatique, 43 (April), 16-17.

Kant, Immanuel (1796/1957). Perpetual Peace. New York: Liberal Arts Press.

Kenen, Peter B. The Use of IMF Credit, Princeton Reprint in International Finance, No. 26 (December).

Krasner, Stephen D., ed. (1983). International Regimes. Ithaca: Cornell University Press.

Laski, Harold (1921). The Foundations of Sovereignty and Other Essays. New York, Harcourt Brace. 
Long, David (1993). "International Functionalism and the Politics of Forgetting." International Journal 48 (Spring), 356-79.

Marchak, M. Patricia (1991). The Integrated Circus: The New Right and the Restructuring of Global Markets. Montreal: McGill-Queen's Press.

Maturana, Humberto (1995). El Sentido de lo Humano. Santiago: Dolmen Ediciones.

Mitrany, Daniel (1943). A Working Peace System: An Argument for the Functional Development of International Organization. New York: Oxford University Press.

Modelski, George, and William R. Thompson (1996) Leading Sectors and World Powers: The Coevolution of Global Politics and Economics. Columbia, S.C.: University of South Carolina Press.

Le Monde Diplomatique (1995). "Les nouveaux maîtres du monde". Special issue of Manière de voir no. 28 (Nov.).

Mulgan, G. J. (1994). Politics in an Antipolitical Age. Cambridge, MA: Polity Press.

New York Times, October 17, 1945, p. 1.

[Page 336]

Journal of World-Systems Research

Norton, Philip, ed. (1996) National Parliaments and the European Union. London: Frank Cass.

O'Donnell, Guillermo and Philippe C. Schmitter (1986). Transitions from Authoritarian Rule: Tentative Conclusions about Uncertain Democracies. Balt imore: Johns Hopkins University Press.

Pritchett, Lant (1996). "Forget Convergence: Divergence Past, Present, and Future." Finance and Development 33 (June), 40-43.

Richmond, Anthony H. (1994). Global Apartheid: Refugees, Racism, and the New World Order. Toronto: Oxford University Press.

Russell, Bertrand (1934). Freedom and Organization 1814-1914. London: George Allen \& Unwin Ltd.

Saul, John Ralston (1995). The Unconscious Civilization Concord, Ontario: Anansi. 
Strange, Susan. "The Limits of Politics." Government and Opposition 30 (Summer 1995), 291-311.

Thibaud, Paul. "Une Europe des Citoyens (III) La necessaire construction d'une legitimite democratique." Le Monde Diplomatique 43 (May 1996), 4-5.

Tobin, James. "A Proposal for International Monetary Reform." Eastern Economic Journal 4 (July/Oct 1978),153-59.

United Nations Development Programme (1992) Human Development Report 1992. New York: Oxford University Press.

United Nations Development Programme (1996) Human Development Report 1996. New York: Oxford University Press.

Wagar, W. Warren (1971) Building the City of Man: Outlines of a World Civilization. New York: Grossman

[Page 337]

Journal of World-Systems Research

Wagar, W. Warren (1996) "Toward a Praxis of World Integration." Journal of WorldSystems Research 2 (no. 2).

Wallerstein, Immanuel (1991). Geopolitics and Geoculture: Essays on the Changing World-System. Cambridge: Cambridge University Press.

Wells, H.G. (1932). The Work, Wealth and Happiness of Mankind. London: W. Heinemann.

White, E.B. (1946). The Wild Flag: Editorials from The New Yorker on Federal World Government and Other Matters. Boston: Houghton Mifflin Company.

Wolff, Edward N. (1995). Top Heavy: Study of the Increasing Inequality of Wealth in America. New York : Twentieth Century Fund Press.

Woolf, Leonard (1916). International Government: Two Reports Prepared for the Fabian Research Department. Westminster: Fabian Society.

[Page 338]

Journal of World-Systems Research 
Columbia: University of South Carolina Press, 1996. xv $+263 p p$. ISBN 1-57003-054-5, \$44.95 (cloth).

\section{Reviewed by Terry Boswell, Emory University}

For the last several years I have begun several papers on global hegemony and leadership by contrasting the Long Cycle perspective of Modelski and Thompson with the World Economy perspective of Wallerstein, Chase-Dunn, and others. At first, this was an easy contrast. While there was always much overlap, the Long Cycle school emphasized world order produced by a world leader with over half the world's naval power. The world economy school emphasized economic dominance over finance, trade, and production, or in some variants, over leading economic sectors. This difference in emphasis allowed me to set up contrasting propositions from the theories that could be tested empirically.

Unfortunately, with this book, the difference in perspectives narrows substantially and I will have to revise my papers substantially. While their earlier work alluded to economic processes, with this book the emphasis shifts rather dramatically from sea power to leading economic sectors. It is a shift that I wholeheartedly applaud. Their discussion of economic and political coordination, as opposed to focusing on one or the other, raises the level of debate to a more sophisticated level. In addition, I find that determining leadership in terms of dominance over leading sectors, which includes the concept to long waves, to be more convincing historically than arguments about simultaneous dominance in finance, trade and production. I also find it more convincing logically as a causal theory, as they now incorporate innovation, than their own past work, which had a functionalist tinge. While they are not alone in advocating leading sector theory, they have amassed an impressive data set to support their claims. The book is a worthy contribution of those grounds alone.

Given this convergence of emphasis, and I should add that World Economy theorists have become more political, are there still important differences between the two schools of thought? Or in other words, can I still salvage my papers? The answer, thank god, is yes.

The most important differences are the following: 1.Is global war necessary for leadership and can a global war occur without 
producing a leader? 2. Are there 3 hegemons or 5 leaders after 1500 ? 3. Were there world leaders prior to 1500 ? and 4 . Does the modern world-system originate around year 1500 or year 1000 ?

[Page 339]

Journal of World-Systems Research

1. Global war is still a necessary part of leadership for long cycle theory, but only a likely probability for world economy theory. Global wars, those wars fought between great powers in which world leadership is contested, are only included in their study if the war produced a world leader. This makes for a tautological relationship between leadership and war, a problem world economy theory avoids by making a clearer separation between economic hegemony and world leadership. Levy, for instance, lists 5 global wars that Modelski and Thompson ignore. They even leave out the Thirty Years War, which was one of the world's most devastating and most politically important wars prior to 1914. Perhaps their next book will explain why this and other global wars are not included and how their theory would account for them.

2. World economy theory finds 3 hegemons since 1500 , the Netherlands, United Kingdom, and the United States. Long cycle finds 5 world leaders, the same three plus an 18 th century British leadership and a 16th century Portuguese one. The difference, of course, is in how one defines hegemony, leadership and leading economic sectors. On page 83, Modelski and Thompson say that "Global system leaders are not hegemons. They do not dominate all economic and political activity." But this is a straw man version of hegemony. Let us take a leading sector version, where hegemony is dominating (i.e., over $1 / 2$ ) leading economic sectors. Then hegemony and leadership should be about the same, except that Modelski and Thompson still use sea power to date hegemons, rather than their own data on leading sectors.

3. They also have $2-5$ possible leaders before 1500 . I must admit in being a bit confused in reading their book as to these early world leaders. Table 8.5 lists Northern Sung, Southern Sung, Genoa, and Venice. Table 9.4 lists the same except it adds the Mongol world empire and drops Genoa. World economy theory, at least until recently, drew a distinction between world empires and world-systems that would exclude most of their early cases, although I must admit, not all of them.

[Page 340]

Journal of World-Systems Research 
4. World economy theory also drew a distinction between the capitalist world system, where one has accumulation of profits from commodity exchange of necessities, versus coercive accumulatio $n$ or preciosity exchange in other systems. The capitalist world system emerges in the period of 1450 to 1650 , with a decisive turning point around 1500 with the European discovery and conquest of the Americas. Modelski and Thompson note that the key element to this distinction is a world market that connects political units into a system, over which a state can lead, but is incapable of subsuming other units into an empire. With a world market, one has a transition belt for innovations, and thus the emergence of economic long waves. They claim that a world market began in China around the year 1000. Some of this difference is over amounts or degrees -- to what extent were market relations central prior to 1500 , did they include necessities, was the market fully a world one?. Other theorists, such A. G. Frank, drop the question of necessities as a bogus distinction, and can thus find a world system that stretches back another 5000 years. This leads to a necessary, and so far unresolved, debate over what constitutes a system.

We cannot resolve this issue here, but let me throw a wrinkle in the pre- 1500 versions. Starting around 1550 , with the long rise of Dutch hegemony, sea trade begins to climb at an exponential rate. This not only changes the basis on wealth in the European core from political power to economic efficiency, but the core states go on to subjugate the rest of the world through colonial conquest. No previous period of world history is comparable. There is a profound qualitative transformation around 1500 in the amount of trade and in its political and social importance, a transformation made more obvious, ironically, by knowing that a world market had existed for 500 years prior or that some sort of system or network existed for 5000 years prior, yet without a similar qualitative change occurring. Capitalism is a fine name for the change as far as I am concerned, but call it what you want, the transformation still must be explained.

Terry Boswell

Department of Sociology

Emory University

Atlanta, GA 30322

[Page 341]

Journal of World-Systems Research 

ECONOMICS.

Columbia: University of South Carolina Press, 1996. xv $+263 p p$. ISBN 1-57003-054-5, \$44.95 (cloth).

Reviewed by Robert Denemark, Political Science, University of Delware.

LEADING SECTORS AND WORLD POWERS is the latest entry in a growing literature on the social science of long term change. It well illustrates the increasing quality and sophistication of that effort. George Modelski and William R. Thompson address the interaction of economic growth, political leadership and systemic war. This is not a new question, and some 40 alternative treatments are reviewed in a highly efficient manner.

Modelski and Thompson find order where others have not in part by avoiding some a priori biases. While they look at nation-states, they are not trapped by national level boundaries. Some of the relevant variables come in nation-state packages, but just as many are either sub- or supranational. Nation-states are not reified, nor for that matter is the global system.

The authors also refuse to take the boundaries of "capitalism" as their necessary limits. A central focus of their model is innovation, which they wisely recognize in both its commercial and its technological forms. Since innovations can affect all market systems, not just those of 'capitalist' or 'industrial' periods, Modelski and Thompson are not constrained by any of the dates variously associated with those eras. They instead follow McNeill's (1982) suggestion that the modern market system emerged in China around the 10th century, and extend their analysis to that point.

Finally, Modelski and Thompson ignore the warnings of scholars from Kondratieff and Schumpeter forward who complain that the data necessary to establish longer term cycles or trends is simply not available. They are successful in gathering an impressive array of data for the post- 1500 period, and in putting together an informative narrative account of $\mathrm{K}$-waves and system leadership for the 500 years preceding that point as well. The result is a global level treatment of broad processes over the very long term. Modelski and Thompson prove that with some effort, the historical record can be made to yield far more specific information than most might imagine.

Political and economic cycles rest at the heart of their model. Fifty to sixty year long Kondratieff (K-) waves are said to be initiated by the bunching of innovations. Growth slows 
when diffusion or competition reduces returns. One hundred to one hundred twenty year long leadership cycles are also identified. These include phases of agenda setting, coalition building, macro decision, and global leadership.

These two sets of cycles are said to coevolve. Innovations generate economic growth and wealth. Increasing wealth provides the incentive to seek to structure the global system, along with the resources needed to engage in agenda setting and coalition building. With growth comes competition among great powers over which will make the rules. This competition, or the fear of falling behind, provides the impetus to war.

[Page 342]

Journal of World-Systems Research

War retards economic growth, in no small part by inhibiting trade. It also determines which state will next lead the system. As a result the downturn is relatively short. With key competitors out of the picture, markets reopening, and the conversion of war-time innovations to new purposes, we find the start of a new K-wave. This second wave is likely to be founded in part upon the fundamental innovations of the first.

Global leadership declines as the second K-wave abates. The global order breaks down. We enter new eras of agenda se tting and coalition building. Though it is possible for the lead economy to reproduce itself, this is unusual. Older technology and older solutions become standard fare in the lead economy. Sunk costs retard the use of newer innovations. New problems, new markets and new resources are likely to form the foundation for the next innovation driven K-wave.

Modelski and Thompson identify four attributes that facilitate the rise of a new lead state. It must be one of the existing major economies, as some participation in previous $\mathrm{K}$-wave upswings provide necessary levels of wealth. It must have a strong military with the ability to extend its power. This is defined in terms of naval strength, which continues to be a vital asset even in the age of air power. It is likely to have a relatively open society, which Modelski and Thompson argue will aid in the creation and adoption of innovations, in the setting of global agendas, and in coalition building. A general sense of responsiveness to global problems is identified as the fourth important attribute.

The finished model includes two $\mathrm{K}$-waves which animate one long cycle of political leadership. The first wave provides the resources necessary for successful agenda setting and coalition building, and peaks before a major war. The war decides the 
question of system leadership, and slows the economy. The new leader emerges with a preponderance (50\% plus) of global naval capacity. A second K-wave follows the war. As it slows, political leadership is contested, disorder increases, and new innovations emerge to provide one of the major economies with the resources necessary to prevail.

Empirical analyses of each of these predictions are undertaken. More formal data are used for the post 1500 period, about which information is more available and comparable. The hypothesized temporal ordering among innovation based economic upswings, war, and naval supremacy, is well supported. Equally supportive are the narrative chapters on Sung China and the northern Italian city-states of the Renaissance. Both the K-wave and leadership cycles are well illustrated.

[Page 343]

Journal of World-Systems Research

Renaissance Italy is linked to Asian markets and technology, and serves to translate the K-wave and political cycle phenomena from China to Europe. It is good to have a picture of how the $\mathrm{K}$-wave and long political leadership cycle came to Europe, which shortly after grew to prominence. Nonetheless it seems that "global" leadership never really rested in northern Italy in anything like the manner that it belonged to the Chinese or even the Dutch. There may be more to be found in Asia, at least about $\mathrm{K}$-waves, and that would make Modelski and Thompson's transition to a Eurocentered analysis in the early 1400 s a bit premature.

By the end of the two empirical sections little doubt remains as to the existence of both $\mathrm{K}$-waves and long leadership cycles prior to the onset of capitalism. Relevant data are available and supportive, and Modelski and Thompson use them in a clear and efficient manner.

The review of the relevant literature, the building of the model, and the sections on verification are all well and precisely written. Definitions are clear, chosen measures are well conceived, and the book is written with precision. If anything it is perhaps a bit too sparing. For example, more information on how innovation was defined and the manner in which data on innovation were gathered would have been helpful. It is clear that Modelski and Thompson do not fall into the trap of simply identifying the times and places where we might expect innovations to emerge and searching for them only then and there. But they fail to tell us enough about their search. Innovation emerges as a central dynamic, and the work would have been stronger if we were told us more about it. 
Chapter 8 of the book, nestled between the end of the data based chapters and the beginning of the more narrative accounts, has two parts. Its methodological half is designed to deal with criticisms of structural analysis and introduce the concept of social evolution. Its other half seeks to place this study of roughly 1000 years into an even broader picture of human history.

Macro level analyses are more and more subject to the criticism that they are illegitimate because they lack a microfoundational base. Most of these criticisms, based on the arguments of methodological individualists, are devoid of merit. But more subtle criticisms exist that warrant consideration. How, for example, does one decide among competing structural level theories when they are indeterminate, that is when they fail to make unique predictions? In such a case, a resort to individual level or microfoundational analysis would provide an additional layer of analysis by which to judge. There is also the unfortunate tendency for older structural and cyclical analyses to adopt a deterministic air. Microfoundational groundings can help guard against this as well. Modelski and Thompson do an excellent job of avoiding both of these problems, in part by leaving the door open to micro-level considerations. They trace the impetus to innovate to the individual level, and are quick to acknowledge the ability of individuals to recognize and perhaps even ameliorate tendencies toward systemic war that their model predicts for the years around 2030. While methodological individualists might still call them bad names, no sophisticated student of social science methodology will miss the quality of their arguments in this regard.

[Page 344]

Journal of World-Systems Research

A sense of social evolution provides this work's guiding methodology. The authors show that social evolution need not be teleological or directional. Instead, and contrary to rational choice methods, social evolution stresses changeable preferences and constraints, trial and error, a focus on institutions, transitions, and the long term. This is well illustrated by K-wave dynamics: ... each K-wave builds on the conditions created by earlier innovations, and in its turn, gives rise to problems that future innovations will have to resolve ... K-waves are both path-dependent and future oriented and they are best understood if viewed in clusters (p. 130).

The result is a superior method of understanding social processes that is historically sensitive, avoids the fallacy of 
determinism, and allows for a holistic apprehension of its subject. My main concern is that the few pages devoted to the discussion of social evolution are once again too few. It is an important methodology about which more ought be said. Modelski's recent work on evolutionary paradigms in the social sciences, (Modelski and Poznanski (1996) and Modelski (1996) would be well considered prior to reading this longer volume.

Chapter 8 also introduces a longer term historical-evolutionary perspective. Four K-waves may be grouped into a "period" with innovations that share a common thematic underpinning and with their own structure of base building, networking, breakthrough and payoff. Four "periods" make up an even longer "global economy process." These global economy processes are also paired, the first laying the foundation for the full development of the second. The whole evolutionary schema is suggested to extend in roughly 1000 year increments from the 3,500 BCE onset of the Bronze Age through the latest, which began about 1850 .

This broader perspective is boldly conceived. It faces two problems. The first is familiar. Too few pages are devoted to it. The second is more problematic. The division of human history into neatly packaged $50 / 60,100 / 20,200 / 240$, and approximately 1000 year increments seems all too handy. What explains this temporal uniformity across so long a sweep of human history? Is it something inherent in the dynamics of innovation, which then provide a more or less stable 50 to 60 year $\mathrm{K}$-wave foundation for the longer periods and eras? Could it be something else? Nowhere in this work, to its great credit, is there much hint of teleology or determinism. What then drives such apparently uniform cycles with their provocatively round numbers? It is a paradox the authors must eventually address.

The final chapter concerns the future, where information technology not surprisingly emerges as the next lead sector, and the U.S. and Japan struggle for lead state status. It is alternately possible, according to the authors, that globalization may make national leadership obsolete.

[Page 345]

Journal of World-Systems Research

Of far greater concern is the coming macro-decision phase. The dual K-waves of the U.S. political leadership cycle have passed, and a new wave began in 1973. We ought be experiencing upheaval and dislocations of various sorts, then new periods of agenda setting and coalition building. The macro-decision phase, traditionally associated with global war, ought be upon us about 
2030. Such a war would be tremendously destructive. The authors are quick to remind us that within their framework nothing is inevitable. Modelski and Thompson consider the arguments against such a war: weapons systems are increasingly lethal, leadership denationalization may obviate war as an instrument of transition, larger international organizations may prove better tension managers, or the diffusion of democracy might enlarge the "zone of peace." Anything remains possible.

This is an excellent work. It is provocative, well conceived, carefully executed, and precisely written. It raises fascinating questions and provides interesting tools with which to address them. Both its substance and its methods will be of interest to social scientists from a variety of fields. This work has a lot to say to all of us.

\section{References}

McNeill, W. (1982) The Pursuit of Power, Chicago IL: University of Chicago Press.

Modelski, G. (1996) 'Evolutionary Paradigm for Global Politics', Iternational Studies Quarterly 40: 321-42.

Modelski, G. and Poznanski, K. (1996) 'Evolutionary Paradigms in the Social Sciences', International Studies Quarterly 40: 315-19.

[Page 346]

Journal of World-Systems Research 
Barbara Stallings, ed. GLOBAL CHANGE, REGIONAL RESPONSE: THE NEW INTERNATIONAL CONTEXT OF DEVELOPMENT. New York: Cambridge

University Press, 1995. xviii + 410 pp. ISBN 0-521-47227

$\$ 59.95$ (hardcover); ISBN 0-521-47806-5 \$17.95 (paper).

Reviewed by Gerardo Otero, Department of Sociology and Anthropology, Simon Frasier University, Burnbay, British Columbia, CANADA

Barbara Stallings and collaborators have produced an extremely useful synthesis of developments in the world economy over the past 15 to 20 years, with thoughtful analysis and generous statistics to support it. Five economic processes are seen to constitute the main context for international development in GLOBAL CHANGE, REGIONAL RESPONSE. The first two -- the end of the cold war and new relations among advanced capitalist powers -- constitute the structure for the new global system; while increased globalization of trade and production, shifting patterns of international finance, and new ideological currents that revolve around market-orientation constitute the main links that unite core countries and their peripheral areas. Defining development as economic growth plus equity, the authors argue that the developing country hierarchy that emerged in the 1980s, with the conversion of a handful of East Asian countries into newly industrialized powerhouses, was closely associated to this international context. As well, because developing countries were associated predominantly with one or another of the dominant powers of advanced capitalism, the United States, Japan, or Europe, such regional links also had major consequences for development. Indeed, a premise of this book is that the Japanese model of development is more conducive to bring forth rapid growth with equity than that promoted by the United States and the international financial institutions.

With the collapse of state socialism, cleavages in the world economy turned toward differences in the styles of capitalism and the growing differences among the United States and its Japanese and European rivals. The latter two seemed clearly more dynamic in productivity and growth. In the case of Japan, its savings and investment propensities, time horizons, the collaborative relationships between public and private sectors as well as between labor and capital, and views about security and equality, made it evident that capitalism is not the same across the globe.

This book's detailed analysis of the effects on developing countries of belonging to one or another region of the world is quite revealing. While Africa has been largely 
detached from the world economy and runs the risk of marginalization, Asian countries have been successfully integrated to the Japanese economy in ways that have allowed those countries to experience substantial economic growth and equity. Latin America is somewhere in between, with higher levels of integration than Africa's.

[Page 347]

Journal of World-Systems Research

Transnational corporations have become the main agents in the globalization process through production and trade, while new capital flows are dominated by various economic actors. These include the international financial institutions, (IFIs, namely, the International Monetary Fund, or IMF; and the World Bank), owners of direct foreign investment and portfolio capital, and governments controlling IFIs and official development aid from advanced industrial nations. Where direct foreign investment (DFI) predominates as the form of capital flow, there may be an overlap with the first link of an integrated production and trade. One problem for developing countries is that capital flows have tended to concentrate among advanced industrial countries, with the proportion increasing from $58 \%$ in the early 1980 s to $86 \%$ at the end of the decade.

But some foreign capital was still flowing toward third world countries. Put schematically, such capital flows changed during the 1980s from private loans to public loans and direct foreign investment. Latin America saw an increased flow dominated by portfolio capital, Asia by direct foreign investment, and Africa by grants and concessional loans. The type of foreign investment flowing into developing countries had a major impact on their prospects for development. Even though DFI was seen as the worse type of international capital in the early 1970 s, at the climax of the import substitution industrialization policies in Latin America, there was a major reassessment after the debt crisis. This was due to the fact that DFI has a much longer term outlook than portfolio capital. By contrast, portfolio capital investments are made with short term views, may cause appreciation of the currency, and can leave the country as soon as they entered.

Regional responses to the international context for development have shaped the impact of global variables. For Latin America, the combined decline of Soviet and European support with increased U.S. direct foreign investment has lead to increased U.S. hegemony. By the 1980s this has meant an increased influence of neoliberalism in shaping economic policy, 
which has also resulted in slow growth and greater inequality. In each third world region there has come to prevail a different meaning of market orientation. While in Asia such orientation has been shaped by Japanese $\mathrm{c}$ apitalism, which includes a substantial state intervention and protectionism of key sectors, Latin America and Africa have followed the Anglo-U.S. lead of capitalism, which has involved massive privatizations and an almost indiscriminate market opening to foreign competition.

Increased economic importance of Japan and the European Union combined with a decline of U.S. military importance have led to two competing views on how the new global economic system will work. One emphasizes multilateral convergence and trilateral management, while the other stresses regionalization into three competing blocs. This book argues that a combination of traits is materializing, simultaneously involving conflict and cooperation, divergence and convergence.

[Page 348]

Journal of World-Systems Research

Barbara Stallings's concluding chapter provides a most interesting elaboration of the mechanisms of influence of the new global economic system in terms of relationships among third world countries and their respective core countries, as well as among the triad of core blocs. By building a "tetrahedron" of such relationships, she offers an analysis based on figures of trade, direct foreign investment, and official development assistance. Trade links are strongest in the countries led by Japan and the United States but weak for Europe. Trade by multinational corporations data is fragmentary, but evidence suggests that an increasing amount of international trade is carried out within firms. This in turn suggests that intrafirm trade raises barriers to entry, which increases the value for developing countries to establish links with multinationals as a way to obtain access to markets.

As mentioned previously, there is an enormous disparity in the distribution of direct foreign investment in the tetrahedron. Japan comes out as the country that sends the largest proportion of its direct investment to the other two core economic regions: $47 \%$ to the United States and $23 \%$ to Europe. The United States sends $36 \%$ to Europe but only $2 \%$ to Japan, while Europe sends only $13 \%$ of its direct foreign investment to the United States and about 1\% to Japan. This means that Japanese investment is almost all financed domestically through its high savings rate, while European countries invest in countries within their own region. The 
United States, by contrast, has come to rely increasingly on outsiders, which introduces a source of international instability and friction.

Japan also comes out as the most generous of the three

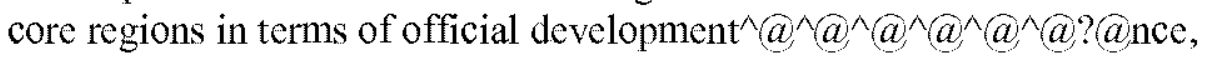
sending $62 \%$ to its integrated countries in Asia, while Europe sends $47 \%$ to Africa, and the United States only $12 \%$ to Latin America. To the extent that these flows are regulated by IFIs such as the IMF and the World Bank rather than governments, they have a dramatic impact in terms of imposing neoliberal ideology. More generally, this book holds the hypothesis that "the policy packages (models) selected by third world countries will resemble those advocated by the countries that buy their goods, supply their finance, and provide their ideological guidance" (365).

Prospects for developing countries will similarly vary according to how they each responds to global trends. In Asia, the NICs are now major players and, as a group, they already exceed Japan's investment in other Asian countries, although they still lag behind investments in other countries and technological capacity. In all likelihood, though, they will play a major role in integrating China and Indochina into the Asian regional economy. The situation for Latin American countries is much more heterogeneous in terms of their potential for hemispheric integration, and it also depends on whether the U.S. Congress will agree to preferential trade relations with more of its southern neighbors beyond Mexico. Finally, there is a strong concern that Africa will be further displaced by the European Union in favor of Central and Eastern Europe. In the long run, a strengthened South Africa might provide an important growth pole capable of integrating some of the Sub-Saharan countries, but this may be well into the future. In addition, argues Stallings, "parts of South Asia, the Middle East, and even Latin America could also end up in this group" of marginalized states (386).

[Page 349]

Journal of World-Systems Research

This book represent a great advancement in the description and explanation of global economic processes, but its focus tends too be almost exclusively economic. The editor of this collection was explicit in her introduction about important aspects that were excluded from analysis: democratization, ethnic and religious conflicts, and environmental problems. Obviously one cannot expect that all 
relevant aspects of development will be treated in a single volume. But my critique centers not so much on the absences but in the selected approach to dealing with the problems addressed. Throughout the book it is assumed that states are the only valid actors in making policy choices. It is only in the last page of the book that the editor acknowledges that some bottom-up approaches may emerge in searching for alternative development paths. Even on this point, though, the implication remains that states from developing countries will be the ones looking, for instance, for alternative development partners. The book does not take into account that the social consequences of neoliberalism are bringing forth new social forces emerging from civil society, rather than the state. Invigorated social movements may thus become effective forces which states will have to reckon with in formulating policy. Neoliberalism is becoming increasingly contested and the social and political problems it is causing may determine that its days (or years?) are counted.

This critique, however, shrinks when compared to the accomplishments of GLOBAL CHANGE, REGIONAL RESPONSE. This book will become standard reference for any serious student of development in the age of globalization. It is a must-read for specialists, and it could be fruitfully used in upper division and graduate courses of development economics and economic sociology. I give it my strongest recommendation.

[Page 350]

Journal of World-Systems Research 
Graeme Donald Snooks. THE DYNAMIC SOCIETY: EXPLORING THE SOURCES OF GLOBAL CHANGE. London: Routledge, 1996. xvii +491 pp. ISBN 0-415-13731-4, \$24.95 (paper).

Reviewed by Stephen K. Sanderson, Department of Sociology, Indiana University of Pennsylvania, Indiana, Pennsylvania, USA

In this extraordinary book, the Australian economic historian Graeme Donald Snooks seeks to do not only the impossible, but the unthinkable: construct a single theoretical model that is capable not only of explaining all of human history and prehistory, but all of the most important transformations that have occurred on earth over the past four billion years! And he nearly pulls it off. Snooks formulates a model that he variously calls MATERIALIST MAN or DYNAMIC MATERIALISM. This model assumes that both genetic and social change are driven by a similar mechanism, which is the desire to gain control over resources so as to maximize the probability of survival and material prosperity. Applied specifically to humans, Snooks?s model holds that humans have an innate desire to increase their wealth and power. Indeed, he claims that they have an insatiable desire to accumulate material possessions. The history and prehistory of human societies is therefore a complex tale in which humans have adopted one or another of four basic strategies in order to achieve their objectives: family multiplication, technological advance, conquest, and commerce. Societies may use more than one of these, but one is usually dominant, especially in the most successful societies. Strategies are chosen for their effectiveness, within the total context of social, cultural, and historical circumstances, in promoting economic well-being and growth. However, any given strategy will eventually exhaust its potentialities, and a new one must then be taken up.

The strategy of FAMILY MULTIPLICATION was the dominant strategy of achieving economic well-being throughout all of human prehistory. It involved producing offspring who would eventually migrate and fill up surrounding territories. According to Snooks, this gave humans greater control over natural resources through the extended family. The big problem with this strategy was that, although it permitted a certain level of material well-being, it was unable to generate any real economic 
growth or raise living standards. As a result, other strategies came into the picture.

One of these was the TECHNOLOGY strategy, which involves the invention and deployment of new or better tools and techniques. It was often used throughout human history, but usually only as a subsidiary strategy. As a primary strategy, it has been most notably employed in Europe between about $\mathrm{AD} 1000$ and 1500 , and then again in Europe beginning with the Industrial Revolution of the late eighteenth century. Why has it been so little employed? Snooks?s answer is that it was generally too expensive in comparison to other strategies. Snooks is highly critical of the conventional assumption made by historians that the agrarian civilizations of the ancient world gave little emphasis to technological advance because they were essentially uninterested in economic growth. They were keenly interested in such growth, he says, but had more cost-effective ways of achieving it.

[Page 351]

Journal of World-Systems Research

The most important of these other growth-inducing strategies was CONQUEST. This involved the military invasion of other societies and their incorporation into the political structure of the conquering state. The economic benefits of this strategy were many, including ?additional agricultural land; additional labour in the form of slaves and soldiers; additional fixed capital in the form of captured military equipment, irrigation systems, buildings, transport facilities, etc.; treasure; and additional tax revenue? (p. 276). This strategy was preferred to all others because it was the most cost-efficient and produced the greatest return on investment. In order to achieve this return, ancient civilizations had to give emphasis to one form of technological advance, that involving military technology. The advance of military technology in the ancient world occurred, Snooks says, because war was not a game but a business, and in fact a very big business.

In his explication of the conquest strategy, Snooks discusses at length the Assyrians, the Macedonians, and the Romans as leading examples. But China, he argues, did not really follow this strategy, and in fact could not follow it, because of a lack of suitable surrounding societies that were worth conquering. China instead relied mainly on 
the family multiplication and technological strategies at various points in its history.

Conquest produced great material gain for its conquerers, but on a global scale it was a zero-sum game. The remaining strategy, though, that of COMMERCE, was capable of allowing societies to break out of this zero-sum straightjacket. The commerce strategy is, for Snooks, essentially one of trade. It could only be effectively employed by societies that had a favorable geographical location, such as on a major body of water, or along the path of a land trading route. Societies in highly geographically and economically differentiated regions might also benefit from trade. Snooks?s leading examples are ancient Mesopotamia, Minoan society, the Phoenicians, classical Athens, the Italian city-states of Venice and Genoa at the time of the Renaissance, and Europe between the sixteenth and eighteenth centuries.

I found THE DYNAMIC SOCIETY to be an extremely provocative read and compelling in many ways. In my view one of the most compelling features of the book is its resolute materialism. Snooks not only defends his MATERIALIST MAN against what he regards as the conventional view of social scientists and historians, MORAL/POLITICAL MAN, but he grounds his economic materialism in a deeper Darwinian materialism. Humans, for Snooks, are Darwinian organisms, which is to say that they have been built for a struggle for survival and a maximization of material advantage. It seems to me that this grounding assumption is not only fundamentally correct, but absolutely necessary to a proper understanding of the nature of human society, its historical evolution, and its future possibilities.

[Page 352]

Journal of World-Systems Research

Snooks?s model of MATERIALIST MAN leads him to many crucial insights. One of the most important is his argument that people usually do not struggle for power for its own sake, but rather seek it because it will promote the realization of material advantage. Power, he says, is largely about economics. Perhaps the best example of this is war. Snooks has exactly the right response to Weberian theorists like Michael Mann who assert that the military objectives of agrarian civilizations were essentially independent of economic objectives. War in the agrarian world, Snooks tells us, was all about economics, because 
conquest was the most cost-efficient strategy of material gain.

But although I have found Snooks?s broad outline of the flow of human history quite compelling, I have some serious reservations regarding a number of details. I would question, for example, his notion of family multiplication as a general economic strategy followed in Paleolithic societies. What Snooks seems to mean by this is population increase in order to provide an adequate labor force. Such a strategy certainly makes sense in situations where labor is scarce, but the real problem for Paleolithic and early Neolithic societies is too many people, not too few. A great deal of anthropological and archaeological evidence suggests that societies at these evolutionary levels are far more preoccupied with controlling numbers than with expanding them. And how, exactly, would family multiplication work in such societies? Among hunter-gatherers and horticulturalists, for example, when a camp or village begins to press too severely against resources a new camp or village will be hived off and go its own separate way, thus having little interaction with the original settlement. Later in the book (p. 227) Snooks does acknowledge the existence of family planning as an alternative to family multiplication, but this appears suddenly out of nowhere and is never system atically theorized.

Moreover, Snooks is not very clear about just why humans abandoned the family multiplication strategy in favor of one of the others. Part of his answer seems to be the inability of technologically primitive societies to raise living standards beyond a minimal level. But this is extremely questionable. Evidence marshalled by anthropologists and archaeologists in recent years suggests that living standards were actually higher, as measured by nutrition and health, among Paleolithic hunter-gatherers than among Neolithic horticulturalists and later agriculturalists. And why? Because of growing population pressure, which itself was very likely the cause of the shift to cultivation in the first place. In fact, Snooks seems to have a general misunderstanding of the relationship between technological development and the standard of living. He insists, for example, that the successful employment of the conquest strategy in ancient civilizations raised the standard of living for everyone. But this is very difficult to accept. Most peasant farmers 
in agrarian civilizations were worse off, sometimes much worse off, than both early Neolithic cultivators and Paleolithic hunter-gatherers. The standard of living has generally DECLINED throughout human history and prehistory, at least for the average individual, and it was only with the rise of capitalism and the Industrial Revolution that living standards began to rise dramatically for the mass of the population.

[Page 353]

Journal of World-Systems Research

I also have some questions regarding Snook?s specific employment of his four economic strategies. To take just one of the more prominent examples, consider Snooks?s claim that Europe between AD 1000 and 1500 relied heavily on the technology strategy. To support his claim he is able to cite numerous examples of technological development during this time, but isn?t it just as logical, if not more logical, to regard European societies at this time as employing the commerce strategy. William $\mathrm{McNeill}$ has argued that the world as a whole experienced a tremendous jump in the level of commerce after AD 1000, and certainly Europe, in particular the Italian city-states of Venice and Genoa, was a huge part of this commercial thrust. In fact, why separate the technology and commerce strategies in this case. Could it not be persuasively argued that Europe was using technological advance to promote a commerce strategy, just as the ancient civilizations promoted the development of military technology to support their conquest strategies? And what about the period since the Industrial Revolution? Once again Snooks refers to this period as one characterized by the use of the technology strategy, but could we not argue that it was really the commerce strategy -- perhaps better labeled the CAPITALIST strategy, since it was world production as well as world trade that was involved -- that was dominant and being served by technological advance?

Snooks is an economic historian, and THE DYNAMIC SOCIETY reads like it was written by one. There is certainly nothing wrong with that, but Snooks gets himself into trouble by seldom if ever looking at world history as a sociologist would. As already indicated, I agree with the rational choice grounding assumptions of this book, but one cannot simply stop there. This book seems to contain ONLY individuals, there being little if any recognition of 
the importance of social classes and economic inequalities as strongly implicated in world historical development. A glaring example of this absence involves Snook?s analysis of Roman conquest. As he puts it, ?Conquest was a business pursued to achieve the materialistic ends of ALL ROMAN CITIZENS? (p. 293; emphasis added). ALL ROMAN CITIZENS?! Does Snooks really believe that the needs and concerns of all Roman citizens, rather than those of Roman elites, were being considered by the Roman polity in its mapping out of its objectives? Indeed he does, for he says at the beginning of the book that ?the dynamics of human society arises from the decision making not just of small elites but of all members of society both male and female throughout the world? (p. xiv). Although elites may capture a disproportionate share of the economic surplus, he says, they me rely express the general desires of humanity. If we shift our focus from the ancient world to modern times, we run into a similar problem. The modern world, many would say, is quintessentially a capitalist world, but capitalists are strangely absent from Snook?s view of this world. There are just individuals pursuing their economic objectives, all of which are the same. Having said this, it will come as no surprise to readers of this review that Snooks makes no mention of world-system theory or any of its formulators, a glaring omission it seems to me.

[Page 354]

Journal of World-Systems Research

Since I am running out of space, let me make just two more critical points. I find highly persuasive Snook?s claim that societies select economic strategies on the basis of what will produce, under particular historical and social circumstances, the best material results for the lowest costs. I think he is right that the conquest strategy was the principal strategy of the ancient world because it was economically superior to the commerce and technology strategies. However, Snooks provides precious little, if any, empirical evidence to support this view, or for his view of the superiority of the other strategies under different circumstances. Snooks argues his case well, but hardheaded empiricists will be put off by the lack of any convincing hard data to back up his argument.

Finally, it should be noted that Snooks comes off 
as a radical antienvironmentalist. He is openly hostile to the view of scientists like Meadows, Meadows, and Randers in their book BEYOND THE LIMITS that we need to be slowing economic growth and reducing environmental depletion or face possible catastrophe in the next century. For Snooks, this is the worst possible prescription, for it would reduce the intense competitive pressures that have been responsible for economic growth throughout world history. And he is certain that humans will be able to respond to the current challenge with the technological means to make continued economic growth possible. He could be right, of course, but much more caution seems to be called for. Never before has human society been confronted with the kind of ecological impact that the current economic system is generating, and never before has the time period within which massive technological change is required been so short. The current situation is, therefore, unlike all its predecessors, and that should not be taken lightly.

My grand conclusions on Snooks are therefore mixed, but I have to admit that I found this book tremendously exciting. Who should read it? Quite simply, all scholars who are concerned with BIG HISTORY, whatever their theoretical orientation or political stripe. It should have a wide audience, and will be both vigorously defended by some and bitterly attacked by others. I am well aware that its Darwinian and rational choice foundations will be strongly resisted by world-system theorists, but I have long believed that these are exactly the right assumptions for world-system theorists to adopt. Indeed, for me world-system theory only makes sense in light of such assumptions. And this should be especially the case for those, such as Frank, Chase-Dunn, and Hall, who wish to posit world-system-like activities thousands of years earlier than AD 1500. Let?s face it, this is what humans are like whether we like it or not.

[Page 355]

Journal of World-Systems Research 
Pacific Asia Resource Center. THE PEOPLE VS. GLOBAL CAPITAL: THE G-7, TNCs, SAPs, AND HUMAN RIGHTS. Report of the International People's Tribunal to Judge the G-7, Tokyo, July 1993. New York: The Apex Press, 1994. vii + 163 pp. ISBN 0-945257-23-6 \$14.95 (paper).

Reviewed by Jan L. Flora, Department of Sociology, Iowa State University, Ames, Iowa, USA

The International People's Tribunal to Judge the G-7 was convened in Tokyo in 1993 to coincide with the G-7 meetings also held in Tokyo. The G-7 group consists of the Finance Ministers and Heads of State of Canada, France, Germany, Great Britain, Italy, Japan, and the United States. Its focus is the world economy, although other urgent items are discussed. The Tribunal was initiated in 1992 at a Washington meeting of $100 \mathrm{NGO}$ activists. It is affiliated with the Rome-based Permanent People's Tribunal. The Tribunal to Judge the G-7 gathered evidence and, utilizing international law such as the Universal Declaration of Human Rights, judged the G-7's "complicity" in the present global capitalist economic system, and in particular the Structural Adjustment Programs (SAPs), enforced through the International Monetary Fund (IMF) and the World Bank.

This little book contains testimony of individuals from Japan, India, Malaysia, Indonesia, the Philippines, Sudan, Jamaica, Grenada, Nicaragua, and Brazil affiliated with universities, independent research institutes and other NGOs. It contains an eloquent statement from a farmer from Japan. It concludes with a document of indictment, which summarizes the case against the G-7 in straightforward language. Testimonies cover

The testimonies are uneven. Some are excellent and well documented. Others critique the capitalist development process generally and at least one (Budiman) presents a list of major debtor countries suggesting that Indonesia ranks second only to India in total international indebtedness. The table does not list either Brazil or Mexico, both of which have larger debts than Indonesia.

SAPs are agreed to by the debtor country as a condition for receiving a SAL (Structural Adjustment Loan) from the IMF. Generally, other lending is keyed on approval of the SAL 
and acceptable progress toward fulfilling the SAP. The SAPs generally contain specifics for accomplishing the following: reduction of the size of the government and the fiscal deficit, privatization of particular government enterprises, liberalization of foreign investment, and "getting prices right" including currency devaluation, substantial tariff and domestic subsidy reduction.

\section{[Page 356]}

Journal of World-Systems Research

While presenters agree that the import-substitution statist approaches previously pursued by many Third World governments had ultimately failed the masses. However, they argue, the SAPs were designed above all else to ensure that transnational corporations (TNCs) could operate freely throughout the Third World. While ostensibly designed to encourage more efficient production and delivery of services in debtor countries, citizens in those countries was not served by the SAPs^?neither in the short nor the longer term. Presenters at the Tribunal suggest the following reasons: 1) The SAPs result in debtor countries "eating their seed corn." Investments in human capital (including both educational and health services) and infrastructure have been curtailed sharply in many countries in order to shrink government. Jennifer Jones, a Jamaican NGO leader, shows that the percentage of the Jamaican national budget represented by the Ministries of Construction (Roads and Housing), Public Utilities and Transport, Agriculture, and Youth and Community Development, and Local Government declined by from half to $70 \%$ from the 1970 s to the 1990 s. Per capita expenditures for education and for health declined by about $1 / 5$. Only the percentages for the Ministry of National Security and the Ministry of Finance grew. The latter, which manages and pays the national external debt, represented over half the total budget by the early 1990s.

2) Isagani Serrano, Vice President of the Philippines Rural Reconstruction Movement, points out that "getting the prices right" is a good deal more complicated, because of externalities, than is suggested by the free marketers. He points out, "Structural adjustment was just as environmentally blind as the previous State-dominated structures that it was trying to undo" (p. 109), and 
argues that cutting back spending "undermined the government's capacity for environmental management" (p. 114). He also admits that South Korea cut down $1 / 3$ of its forests while pursuing a successful state-led Export Oriented Industrialization. One might conclude that the culprit with respect to environmental degradation may be economic growth, but the SAPs offer no solution. More broadly, if the SAPs ultimately serve the interests of the TNCs at the expense of the people in debtor countries, then one would not expect the internalization of externalities ${ }^{\wedge}$ ? whether they be deteriorating infrastructure, human capital erosion, or environmental degradation ${ }^{\wedge}$ ?in "getting the prices right."

[Page 357]

Journal of World-Systems Research

3) Maria Clara Couto Soares of IBASE, the Brazilian Institute for Social and Economic Analysis, in the best essay in the book, analyzes the process of debt repayment and assesses the impact of the SAPs in that country. She points out that the foreign debt by 1985 was US $\$ 105$ billion, up $64 \%$ over 1980 , in spite of the fact that Brazil paid US\$91 billion in foreign debt service in that period. In order to make payments on the external debt, the government (lacking a fiscal surplus), issued bonds to purchase hard currency from exporters. This increased the Brazilian government's domestic debt and triggered inflation. Efforts to dampen that inflation brought recession. Annual GDP growth was $1.7 \%$ in the $1980 \mathrm{~s}^{\wedge}$ ? less than the population growth rate. Poverty grew more than $50 \%$ over the decade. And by 1989 , Brazil's debt had actually grown to $\$ 115$ billion. Two sectors in Brazil did quite well--exporters and the financial sector, who were able to make considerable sums through speculation. By the 1990s, Brazil had the greatest income inequality of any country in the world. Soares concludes by saying that structural adjustment and its neo-liberal policies have not provided a base for new development, but rather have eroded the previously developed productive and institutional structure and technological capabilities.

4) The Tribunal's "Indictment" does a good job of discussing the relationships which have weakened the ability of indebted Third World countries to provide for their people: The G-7 desires to remain dominant through the 
"constant expansion of global capital" (p. 126).

However, the global expansion of capital reduces the power of the G-7 nations, as they have become "front men for global capital" (p. 127). The World Bank is also a servant to the TNCs rather than "serving the common good," as was the GATT (now the World Trade Organization--WTO). Indictments include violation of Articles 23, 26, and 25, which forbid denial of the right to work, the right to education and the right to a standard of living adequate for health and well being; usurpation of the sovereignty guaranteed member states in the UN Charter through the imposition of SAPs via secret negotiations and rulings by the IMF and World Bank; etc. These violations are presented in more detail in an introductory essay by Richard Falk, international legal scholar.

While the indictments are well argued, the call to action may be satisfying to those who made it, but not very realistic politically. Organized citizen groups are exhorted to demand compensation from the responsible institutions to those who were harmed by SAPs, and to obtain recognition by G-7 leaders of their of personal responsibility for the suffering that structural adjustment has caused. Based on a secret analysis by the IMF of 66 SAPs which apparently shows almost a total failure to achieve their fiscal, monetary, income growth, and debt reduction objectives, the Tribunal suggests that the IMF be required to compensate "SAPped" countries through debt reduction for the harm done by SAPs to people and that the World Bank compensate persons harmed by its failed projects.

[Page 358]

Journal of World-Systems Research

While these are interesting ideas, I would have been more satisfied if there had also been analysis of possible contradictions in the system and of the circumstances under which the G-7, the World Bank, or others might be persuaded to counter the power of the TNCs. Perhaps, with organized citizen pressure, issues like global warming could become a cause for which the G-7 countries, in their own self interest, would discard free market concepts and provide grants to Third World countries and to their farmers, indigenous peoples, and others to encourage for reducing pollution reduction and rain forest conservation. At what 
point, given the increased capacity and pressure for the World Bank to evaluate projects it supports, will the World Bank conclude that the principles behind the SAPs ${ }^{\wedge}$ ?and eventually the globalizing development model which underlies the SAPs--must be radically altered? There are efforts within the Bank to change the corporate culture from an engineering mentality to one which gives greater importance to social results. How successful those efforts will be is unclear, and may depend also on citizen pressure for internalizing the externalities generated by the TNCs. Only once in this book are the NGO coalitions mentioned which have grown up around the major UN Conferences of the past decade on women, the environment, food security, etc. How might they contribute to such citizen pressure?

This book is aimed at activists, and is written in straightforward prose. It is also appropriate as a textbook in advanced undergraduate courses as well as graduate courses on international development and related topics. At the graduate level it should be supplemented by other readings on Globalization. I expect to assign the four chapters I cited above in the introductory part of my graduate rural development course. Although the "Indictment" chapter has shortcomings, it should generate a healthy discussion on the relationship among actors in the Globalization process and regarding appropriate tactics for diminishing or reorienting the global power of TNCs.

[Page 359]

Journal of World-Systems Research 
Ted C. Lewellen. DEPENDENCY AND DEVELOPMENT:AN

INTRODUCTION TO THE THIRD WORLD.Westport, Connecticut:

Bergin and Garvey, 1995. xi + 272pp. ISBN 0-89789-399-9,

$\$ 69.50$ (hardcover); ISBN 0-89789-400-6, \$22.95 (paper).

Reviewed by Claudia Buchmann, Department of Sociology, Duke

University,Durham, North Carolina, USA

The stated goal of DEPENDENCY AND DEVELOPMENT is to provide an interdisciplinary overview to issues of Third

World development. Lewellen likens the task to a guided tour through the Metropolitan Museum of Art; it is intended to provide a background to a vast and varied subject and a "mental map" for more-focused return visits.

The book begins by addressing various terms used to refer to the poorer nations of the world. After explaining the origin of the term "Third World," its pejorative nature, and the inadequacy of other alternatives (i.e., less developed countries, the periphery, developing nations, the South), Lewellen concludes that all are inadequate yet none are avoidable. After this insightful discussion, I was surprised that he classifies the poorest countries as "the Fourth World," since this classification perpetuates the terminology he deems problematic. The rest of the first chapter discusses features common to most Third World nations -- poverty, economic dependency, soft states, population growth -- and provides a clear sense of what is to follow.

Chapter two contains a "brief history" of major Third World regions (Latin America, Asia, the Middle East, and Africa) which, while perhaps necessary, comes off like a tedious history lesson.Major theories of development, namely modernization and dependency perspectives are the focus of chapter three.Here the author is careful to distinguish among the variants of each (such as the ECLA model, dependency theory, and world system theory). This brief but lucid presentation is well-summarized with a detailed chart of major paradigms and concludes with a call for a greater synthesis of these perspectives. Chapters four and five rise to this call by focusing first on domestic economies and internal factors and then the international economy and external factors in facilitating or impeding development. Chapter five is more cohesive than chapter four and includes one of the best 
short summaries of the debt crisis and foreign aid to date.

These first five chapters provide the new student

of development with a succinct and well-organized

introduction to Third World development but also serve as

comprehensive review for the informed reader.At times,

the text gets bogged down in the tension between

generalization and detail. The author tends to list

numerous countries with little or no elaborationin lieu

of detailed examples of main points.For example, in a

discussionof unequal exchange and raw material exports, eleven countries are presentedin less than one page.

Similarly, four short paragraphs on land reform coverthe

experiences of eight countries.In other cases, statistics

are presentedfor the Third World as a whole without

acknowledgement of the diversity thatis masked by such

summary statistics. Neither strategy works very well.A

more reader-friendly approach would have been to present

one or twocountry-specific examples in greater detail and

leave the categorization of numerous countries to charts or

figures.

[Page 360]

Journal of World-Systems Research

The remaining chapters focus on specific topics -politics, population, environmental problems and human rights -- in a Third World context.Each of these chapters could easily stand alone and they vary in terms of coverage. Chapter seven on population is interesting and inclusive while chapter six on politics is fragmented and misses some major issues.Here, the discussion of strong and weak states is severely limited and there is no mention of the rich civil society that pervades the political sphere in much of the Third World.Although the topic has been the focus of much recent theorizing across many disciplines, it is curiously absent from this volume.In chapters six through ten, as in earlier ones, greater use of charts and figures to present statistics would have aided the reader. As a comprehensive overview to Third World development, the book is largely successful.It encompasses a wide range of theoretical approaches and topics in a concise and well-organized text.Lewellen clarifies terms for the novice but avoids oversimplification in the presentation of most issues.For this reason, DEPENDENCY AND DEVELOPMENT should appeal to a diverse audience.It is appropriate for use in general 
undergraduate classes on development as well as more advanced graduate-level courses.

The book has two weaknesses.First, it only partially achieves the stated goal of being "truly interdisciplinary" (p. x). On one hand, Lewellen, a cultural anthropologist includes a cultural perspective that is missing from many development textbooks. This was a welcome addition. Yet, the contributions of many well-known sociologists of development (i.e., John Walton, Alejandro Portes, Stephen Bunker, Charles Ragin) are neglected in the text and are completely absent from the suggested readings and bibliography. While an interdisciplinary overview of the broad, multi-faceted topic of Third World development is an enormous undertaking, it might have been accomplished with more disciplinary balance.

Finally, as guide for more focused study on a specific region or issue the book falls short. The text contains few citations for follow-up reading.Often the author refers to "some theorists" or "a group of scholars" without providing references.Some sections cite one or two works repeatedly instead of providing a variety of references on the topic. The suggested readings provided at the end of each chapter, although useful, do not make up for the lack of cited material.They include too many general overviews or reports (such as the World Bank's World Development Report) and too few academic books and articles. Nonetheless, the books strengths -- its comprehensive scope and well-organized format -- outweigh these shortcomings. As a result, it should find a place in many courses on Third World development.

[Page 361]

Journal of World-Systems Research 
Thomas R. Shannon. AN INTRODUCTION TO THE WORLD SYSTEM

PERSPECTIVE. 2nd ed. Boulder: Westview Press, 1996. xvii

+ 253 pp. ISBN 0-8133-2451-3, \$59.95 (hardcover); ISBN

0-8133-2452-1, \$19.95 (paper).

Reviewed by Frances V. Moulder, Social Sciences Department, Three Rivers Community-Technical College, Norwich, Connecticut, USA

AN INTRODUCTION TO THE WORLD SYSTEM PERSPECTIVE is the second edition of a text first published in 1989. The author's objective, as stated in the Preface to the first edition, is to "provide students with an accessible introduction to world system theory that is firmly embedded in history." Although aimed at undergraduates, the book will also be of interest to graduate students and others who are looking for a guide into the large amount of theoretical and empirical work in the field.

The book covers the following topics: origins of world system theory; defining characteristics of the world system; history of the world system; structure of the present world system; processes of change; contemporary developments in world system analysis; criticisms of world system theory; and the author's own evaluation of the perspective. Changes from the first edition include addition of a chapter on "New Directions in World System Analysis," and various revisions to reflect changes in the periphery and semi-periphery, dismantling of the Soviet Union, and the end of the Cold War. Shannon also states in the Preface to the second edition that he has attempted to "correct some unintentionally harsh statements in my final evaluation of the perspective that seem to have misled readers about where my general theoretical sympathies lie."

A strength of this book as a textbook is that it attempts to address comprehensively the entire range of concerns of world system analysis. Most of the other available undergraduate texts are more narrowly focused on the economic development of the periphery (e.g. John Isbister, PROMISES NOT KEPT; Philip McMichael, DEVELOPMENT AND SOCIAL CHANGE; Alvin Y. So, SOCIAL CHANGE AND DEVELOPMENT) or on specific world issues (e.g. York W. Bradshaw and Michael Wallace, GLOBAL INEQUALITIES). 
In contrast, Shannon deals systematically with the core and semi-periphery, as well as the periphery, and with a range of concerns, including methodological questions, the issue of pre-modern world systems, hegemonic struggles, the decline of core nations, etc.

The new chapter on "New Directions in World System Analysis" is a definite enhancement. It deals with the analysis of race, gender and culture in the world system; methodological issues; and the debates over the existence and nature of earlier world systems. This chapter demonstrates the continued growth and vitality of the world system perspective. I hope that Shannon will expand the chapter in future editions to include efforts underway to apply the perspective in other areas such as analysis of the environment, urbanization and social movements.

\section{[Page 362]}

Journal of World-Systems Research

Shannon's chapters on the defining charac teristics and history of the world system are especially useful. I know of no other source with so much of the relevant information so clearly stated for an undergraduate audience. I used the first edition several times in courses for advanced undergraduates. Students were invariably grateful to Shannon for helping them understand the history of the world as a coherent system rather than as a confusing array of disconnected or random events and personalities.

Shannon has worked to make the book accessible to student readers. He states in the Preface to the first edition, "I have... avoided assuming very much prior background on the part of the reader. I have learned that one cannot assume even the most basic historical or geographic knowledge when addressing an undergraduate audience." Despite these efforts, the text is probably best suited to well-prepared, higher level students -- advanced undergraduates and graduate students. In my experience, those who have not taken some combination of college-level courses in economics, history and sociology find this book somewhat overwhelming, rather than challenging. For example, the chapters on history, although lucid, are still too abstract for readers with little knowledge of world history. Other chapters require 
a prior introduction to economic terminology. For example, the following concepts are introduced without explanation in chapter 1, "The Origins of World System Theory" -commercialization, capital investment, infrastructure, subcomponents, industrialization, etc. In fairness to Shannon, the book's failure to be more accessible to less advanced undergraduates is partly an outcome of the book's topic, i.e. it is a book about the world system PERSPECTIVE, not a book about the WORLD SYSTEM. Since the world system perspective is a revision of prior thinking in most of the social sciences, it cannot be fully appreciated without knowledge of the thinking it has rejected or synthesized in a new way. If someone were to attempt to write an accessible undergraduate text on the WORLD SYSTEM, they would be freer to write for a wider audience. Interestingly, such books are beginning to appear at the K-12 level! (See, for example, Iftikhar Ahmad et al., WORLD CULTURES: A GLOBAL MOSAIC. This is a social studies text for middle school students which contains insights from the world system perspective (Prentice Hall, 1993). Ahmad is a researcher at the Fernand Braudel Center and has a Ph.D. in Sociology from Binghamton University.)

In sum, Shannon's book is a fine text for advanced undergraduate courses emphasizing the world system perspective, and an excellent reference for graduate students and others interested in the perspective. I trust that it will be a popular text, and hope Shannon will continue to update the book and keep it in print for future use.

[Page 363]

Journal of World-Systems Research 